\title{
Listening to the Dead With Our Eyes: François Olivier-Martin's Library, a Mirror Image of a Legal Historian
}

\author{
SVETLANA KOCHKINA \\ McGill University Law Library, Canada
}

This article reports the results of a study of the private working library of an important French legal historian, François Olivier-Martin (1879-1952). It is demonstrated that a personal research library, being the reflection of the scholarly life, beliefs, and personality of its former owner, can be used as a source of information for historians and biographers. The article describes the process of intellectual reconstruction of the library to its original state and fills the existing gaps in the biographical information about OlivierMartin, especially regarding his life and work during the Vichy period.

KEYWORDS private libraries, book collectors, book collecting, legal historians, book history, François Olivier-Martin, Vichy

François Mauriac famously said, "Dis-moi ce que tu lis, je te dirai qui tu es” il est vrai, mais je te connaitrai mieux si tu me dis ce que tu relis" ("Tell me what you read and I'll tell you who you are" is true enough, but I'd know you better if you told me what you reread'). In recent years, studies of private libraries and collections-some more analytical in nature, some in the form of annotated bibliographies - have been undertaken with a varying, but ever-present, attention paid to the connection between the personality and life of its former owner and the books constituting their private library. ${ }^{2}$ These studies demonstrate that a private library, a private collection, or a personal research library can be regarded as a reflection of the life, personality, or character of its former owner and collector. Roger Chartier talks about the difficult task of historians striving to understand the 'suffering and hopes, rational decisions and extravagant dreams' of men and women of the past but often facing 'only silences, silences of those who never wrote'. ${ }^{3}$ Filling this gap, private book collections and personal research libraries can become inaudible but no less real voices of their former owners and collectors and be used as material evidence to complement information about their lives and work available in other sources or even to act as such in their absence, allowing historians to 'listen to the dead with their eyes'. ${ }^{4}$ 
This article reports on an analysis of the private working library of a renowned French legal historian, François Olivier-Martin (I879-I952). First, it describes the reconstruction of the Olivier-Martin library to its original state. Second, it fills important gaps in the biographical information about Olivier-Martin available in English by bringing together information from French sources while paying particular attention to his activities in the period I940-42. Lastly, it demonstrates, based on the analysis of its contents, how Olivier-Martin's library accurately represents and reflects the intellectual and professional life and personality of its former owner.

\section{History of the Olivier-Martin library}

François Olivier-Martin's research library was during his lifetime one of the most comprehensive private libraries on the history of Ancien Régime French law. It was acquired by McGill University after his death in 1952 with funds donated by a McGill alumnus, Arnold Wainwright. Jean-Gabriel Castel, a Canadian legal scholar and a former member of the French Resistance, who was awarded le Chevalier de la legion d'Honneur and a member of l'Ordre national du Mérite for his services during the Second World War, was a professor of the McGill law faculty at the time and negotiated the purchase of the library. In 1958, the library was formally presented to McGill University and transferred to the Law Library. It was then renamed the Wainwright Collection. ${ }^{5}$ This change of name had a particular significance because the Olivier-Martin library ceased to exist as a separate entity as a library of an important, albeit controversial, scholar. It became a special collection that could and should be developed. During the years that followed this donation, the Wainwright Collection grew from some 700 titles to approximately I600 titles. Over time, with McGill's Law Library moving from one location to another, some of Olivier-Martin's books were transferred to other special collections of the Law Library or even to the general collection. When the card catalogue was converted into electronic format, no provenance notes were added to the cataloguing records. By $20 \mathrm{II}$, the only widely accessible sources of information in English about the former owner, Olivier-Martin, and his library were two articles documenting the fact of the acquisition of the library and woefully lacking some crucial biographical data. ${ }^{6}$ As a bibliographic entity, the Olivier-Martin library became to a certain extent a 'hidden collection' with local-only and staffdependent intellectual access through a typewritten and, as it will be demonstrated later, largely erroneous bibliography compiled in 1960. In the age of the Jimmy Wales 'Google test', when if something is not on Google, it does not exist (or if we extend it to the documented search habits of Internet users, when something is not on the first pages of the Google search results, it does not exist), this type of information about a special collection was hardly sufficient. ${ }^{8}$ The Olivier-Martin library was not a 'hidden collection' in the strict meaning of the term because all the books were listed in the McGill Library's online catalogue. However, because of the absence of provenance information in the records in the McGill catalogue, it was impossible not only to distinguish between the original library and later additions but even to realize that the Olivier-Martin library had been blended into the Wainwright Collection. 


\section{Reconstruction of the library}

In order to study the Olivier-Martin library and to explore the extent to which it reflects the scholarly life, mind, and personality of its former owner, the library first had to be reconstructed to its original state. Also, to make it discoverable and intellectually accessible to the research community as a distinct and separate bibliographic entity, the provenance of Olivier-Martin's books had to be recorded in a publicly accessible source, McGill Library's online catalogue. The task of tracing the past ownership of the books acquired by an academic library some sixty years ago does not presage any of the thrills and challenges attributed to the work of a researcher deciphering a book list found in a medieval palimpsest. From the outside, the work seems mundane, fast, and rather easy to do. Yet, in reality, the task of reconstructing the Olivier-Martin library proved much more difficult and time-consuming. It required the use of several types and sources of evidence, archival and physical, internal and external to the books. Until the beginning of this project, it was believed that an unpublished typewritten analytical bibliography compiled by Dénes de Boronkay and held by McGill Library was the catalogue of the Olivier-Martin library. ${ }^{9}$ However, even a brief examination of this bibliography revealed that it could not be viewed as an authoritative source with regard to the past ownership of the books. It was discovered that the bibliography does not contain all of Olivier-Martin's books; for example, numerous folios are excluded from it for an unknown reason. At the same time, it erroneously lists as formerly belonging to Olivier-Martin multiple books added to the Wainwright Collection between 1958 , the date of the official transfer of the Olivier-Martin library to McGill, and I960, when the bibliography was compiled. For example, the very first book included in the bibliography, a 1689 Abel treatise on the customary law of Brittany, bears proof of a totally different former ownership. ${ }^{\text {IO }}$ It is a Harvard Library duplicate copy that was, according to the bookplate, acquired by McGill Library in 1957 and added to the Wainwright Collection between 1958 and 1960. Another example is a two-volume set, Nouvelle introduction à la pratique ( 1758 ), listed in the bibliography under the number $297 .{ }^{\mathrm{II}}$ This book had never belonged to Olivier-Martin and was donated to the library by a well-known McGill alumnus, R. J. Wicksteed, as documented by Wicksteed's embossed stamp and bookplates. Another common method of tracing the past ownership of books is based on the presence of the donor's bookplate, an ex-dono, pasted in the book by library staff. This method also failed in the case of the Olivier-Martin library. The bookplate 'Ancienne Collection Olivier-Martin presented by Arnold Wainwright, Q.C.' was supposed to be attached only to the books that had belonged to Olivier-Martin. Yet it was found on some volumes that were published years after OlivierMartin's death. A telling example is The Best We Can Do (I958), a book that was not only inscribed as a gift to Arnold Wainwright but also published six years after OlivierMartin's death. ${ }^{\mathrm{I2}}$ Consequently, the presence of this bookplate alone could not be regarded as satisfactory proof of Olivier-Martin's ownership of other books in the collection.

When existing evidence, both external (the bibliography) and internal (bookplates and other marks of ownership), had been proved unreliable, further information about past ownership was sought. Regrettably, the latest preserved McGill Library accession register covers only the beginning of the year I947, while the Olivier-Martin library 
was acquired in 1958. The annual report of the Law Library for the year 1958, found in McGill Archives, mentioned the fact of the acquisition but did not list the titles. Fortunately, with the help of the head librarian of the Law Library, Daniel Boyer, the full inventory of the collection, contained in the bill of lading, was found in the boxes kept in the Law Library's basement storage. The data from the bill of lading were crosschecked with the internal evidence found in the books, bookplates, signatures, and marginalia, as well as with the information from Boronkay's bibliography. This allowed us to establish confidently the past ownership of 775 titles that had belonged to OlivierMartin and to add the provenance information to McGill Library's online catalogue, thereby securing the ownership data from possible loss and making his library discoverable as a separate bibliographic entity available for future study. The reconstruction of this library can be seen as a timely reminder of the need to use multiple sources, both internal and external to the books, for establishing or confirming the past ownership of books in order to minimize the possibility of error.

\section{François Olivier-Martin: Work and life ${ }^{13}$}

Olivier-Martin was a university professor, a doctor of law, a longtime coeditor of the Nouvelle revue historique de droit français et droit étranger, a member of the administrative board of la Société d'histoire ecclésiastique de la France, a president of la Société d'histoire de droit, and a member of numerous scholarly societies. In I937, he cofounded la Société Jean Bodin pour l'histoire comparative des institutions. For his achievements, Olivier-Martin was awarded multiple honorary degrees. In 1932, he became a chevalier of the Légion d'honneur, and in 1936, he was awarded the highest French academic honour and elected to one of the five academies of the Institut de France, the Académie des inscriptions et belles lettres.

Olivier-Martin taught courses on Roman law and French legal history for forty-six years, first at the faculty of law at the University of Lyons, then at the University of Rennes, and between I92I and I95I at the University of Paris, where he succeeded the famous legal historian Émil Chénon, holding the chair of legal history. He was known as a charismatic and talented educator, whose lectures on legal history at the licence level and his more specialized doctoral level seminars enjoyed wide popularity among students. An attentive mentor who always had time for his students, he shaped generations of future French legal historians, who paid him an affectionate tribute by publishing more than eighty articles dedicated to him in various scholarly journals ${ }^{\mathrm{I} 4}$ as well as a pamphlet with his brief biography and the bibliography of his works in commemoration of his retirement. ${ }^{\text {I5 }}$ Olivier-Martin's own extensive scholarship includes nine monographs and more than sixty articles and book reviews. An almost complete bibliography of Olivier-Martin's works can be found in À monsieur François Olivier-Martin (I95I), with three more works mentioned in the endnote to his obituary by Lepointe. ${ }^{16}$ Even unsophisticated searches in the Dalloz, Lextenso, and Persée databases, as well as in Google Scholar and Google Books, show that his works are still widely cited by scholars writing about the history of prerevolutionary French law, French customary law, and the history of professional corporations and guilds in France. However, the legacy of this prominent legal historian is still debated in the French academic community. 
In order to understand fully the impact, distinctiveness, and controversy of OlivierMartin's scholarship it is necessary to take into consideration his personality, convictions, and beliefs as well as the particularities of the development of legal history as an academic discipline in France. It has been underlined more than once that, from I789, France and its people were divided into two 'ideological families', the 'deux familles spirituelles', one representing the Ancien Régime and the other the French Revolution and Republic. ${ }^{\mathrm{I7}}$ Olivier-Martin, while a tireless and rigorous researcher, strict in his methods, and precise and nuanced in his definitions, whose seminal study of French customary law, Histoire de la coutume de la prévôté et vicomté de Paris (1922-30), ${ }^{18}$ is still a model of its kind, was at the same time a monarchist, devout Catholic, corporatist, and supporter of the conservative right, universally known in the Quartier latin to belong to the famille spirituelle of the Ancien Régime. Olivier-Martin's penchant for the institutions and order of the pre-Republican era is unambiguously expressed in all his works and is especially evident in his two other major studies, which are, however, unrivalled in their use of primary sources and are still widely cited despite the ideological bias of their author: L'organisation corporative de la France d'Ancien Régime (1938) and Histoire du droit français des origines à la Révolution (1948). ${ }^{\mathrm{I9}}$ His ideological stance was actively and repeatedly criticized by his opponents, Marc Bloch and Lucien Febvre, the founders of the Annales school of history, and Ferdinand Lot, even though the latter did not deny the qualities and importance of his work. ${ }^{20}$

The pronounced discord between Olivier-Martin and Marc Bloch and Lucien Febvre, rather antagonistic on both sides, was much broader and deeper than any common disagreement between individual scholars. It was a manifestation of the methodological conflict that existed between French legal historians and other historians about the understanding of the notion and the role of the state and legal institutions in the history of the nation. To sum it up briefly, the position of historians was that the views of legal historians on this subject, who were mostly jurists by education, were too narrowly legal, while legal historians reproached historians for their lack of legal knowledge. ${ }^{2 \mathrm{I}}$ The tension was exacerbated still further by the fact that, from an ideological point of view, historians of the Annales school were on the left side of the political spectrum, while most classical legal historians were conservatives (with the notable exception of Adhémar Esmien): Émil Chénon was a militant royalist, Joseph Declareuil an antiDreyfusard, and Olivier-Martin himself a monarchist and the ideologue of the Vichy's corporatism. ${ }^{22}$

The controversy surrounding Olivier-Martin's scholarship and his influence on the development of legal history as a discipline in France has survived to the present time. On the one hand, his works are still widely cited in new publications on the history of French law. 'Olivier-Martin' remains a household name among French historians, quite sufficient in its own right to define the methodological and ideological allegiances of other scholars. Tellingly, for example, Roland Mousnier is characterized as being 'more willing to cite Fustel de Coulanges or Olivier-Martin than Lucien Febvre' in his entry in the Encyclopadia universalis. ${ }^{23}$ On the other hand, sixty-two years after his death, we still await a definitive study of Olivier-Martin's scholarly legacy and his influence on the development of legal history as a discipline, especially on its disciplinary identity. It is only in recent decades that several attempts to evaluate and deconstruct his legacy, among those of other classical legal historians, have been made by Pierre 
Bonin, Anne-Sophie Chambost, Jean-Louis Halpérin, Jean Hilaire, and Jacques Poumarède. $^{24}$

One of the possible reasons for this reluctance to undertake a study of Olivier-Martin's scholarship and his role in the development of French legal history belongs rather to the domain of history and politics than to a purely academic debate. The community of legal historians has been somewhat unwilling to explore the past of some of its members, mostly trying to avoid exhuming their activities during the Vichy regime, libération, and épuration. ${ }^{25}$ For Olivier-Martin, the thorny issue preventing an in-depth study of his scholarly legacy has undoubtedly been his activities as a judge of the Supreme Court of Justice at the Riom Trial in $1940-42$, which, though well known, have been openly acknowledged by his biographers only recently in the entry under his name in Dictionnaire historique des juristes français: XIIe-XXe siecle (2007). ${ }^{26}$

The Riom Trial does not command particular attention from historians. For example, there is no separate chapter dedicated to this trial in the major ten-volume work $\mathrm{La}$ grande histoire des Français sous l'occupation (1997), ${ }^{27}$ and it is only briefly mentioned in other works on this period. ${ }^{28}$ This relative lack of interest can be attributed to the fact that the trial, which lasted for two years and did not result in any conviction, can seem rather mundane compared with other events and enormous human tragedies that marked the Vichy period. Nonetheless, the factual history of the trial is documented in several studies, the most detailed of which is the work by Henri Michel, ${ }^{29}$ as well as in some of the more general texts on the history of the Vichy regime or on the special jurisdiction courts. ${ }^{30}$ It is worth mentioning also that interest in the Riom Trial, which had dwindled after the appearance of the first works on the subject in the I950s and again after the publication of Henri Michel's study, was reawakened in the r99os and 2000 s with an increased interest in the judicial, legal, and administrative aspects of the Vichy regime. ${ }^{3 \mathrm{I}}$

For the purpose of the present study, the Riom Trial is a revelatory event that, through his attitude and behaviour during the trial, highlights the personality and character of one of the judges, Olivier-Martin. The Riom Trial was an attempt by the Vichy government to put the blame for the disastrous defeat and national humiliation of France in 1940 on the leaders of the previous regime, the Third Republic. On I August I940 a special jurisdiction court, the Supreme Court of Justice, was created to conduct the investigation and trial, with Olivier-Martin, a prominent academic and jurist, appointed as one of the judges. The intended political nature of the trial, initiated at a time when public sentiment against the accused was vehemently hostile, was quite evident. If it had been carried out with the usual swiftness of trials of this kind, the sentence and the fate of the accused could have been easy to predict. Fortunately, during the investigation, as well as during the trial itself, the judges approached their task conscientiously and methodically. In almost two years, an enormous amount of documentary evidence was gathered (accounting for more than seventeen linear metres of archival records), ${ }^{32}$ and more than 600 witnesses were called to testify. All these lengthy proceedings could satisfy neither the minister of justice of the Vichy government, Joseph Barthélemy, nor Pétain himself. Barthélemy, who was initially delighted by the thorough and meticulous approach of the judges and especially that of Olivier-Martin himself, and praised him for his 'travail de bénédictin', ${ }^{33}$ was later obviously annoyed by Olivier-Martin's intention to perform his task in this scrupulous and rigorous 
manner without any consideration of what Barthélemy called the public interest, 'le salut publique'. ${ }^{34}$ Pétain's displeasure at the turn the investigation had taken was expressed when in January I94I he created the Council of Political Justice, which had the same task of judging the officials of the Third Republic. The creation of the council, as well as Pétain's speech on I6 October I94I about the expected results of the council's investigation, where he summarily declared the accused guilty, was meant to put pressure on the Riom judges to accelerate their investigation and deliver their verdict. The judges did not protest against this obvious interference and violation of judicial impartiality, nor did they change their attitude towards the investigation and trial. When the trial opened on I9 February 1942, the five accused still facing charges (the charges were not pressed against two defendants, Georges Mandel and Paul Reynaud) were given a full opportunity to defend themselves. So freely did they do so, that, to the indignation of the collaborationist press, the trial initiated by Pétain almost became the trial of Pétain. The hearings of the Riom Trial lasted only for a month and were indefinitely suspended by Pétain as the trial turned out to be damaging for the reputation of the Vichy regime. After the liberation of France, one of the defendants, Léon Blum, a prime minister of the Third Republic during the days of the Front populaire, expressed his gratitude to Olivier-Martin personally for his fair and professional attitude during the trial, while another defendant, yet another prime minister, Édouard Daladier, at the trial of Pétain in 1945, praised all the Riom judges for their professionalism.

Olivier-Martin's acceptance of his appointment to the bench of the Supreme Court of Justice and his behaviour during the trial were entirely characteristic. For Olivier-Martin, Pétain was not only his longtime friend, whom he might have felt compelled to oblige by accepting his role as a judge, but also the legitimate head of French state after the defeat of I940. Olivier-Martin was a French patriot who saw defeat in I940 as a national disaster and was unquestionably loyal to the French state as an institution and to the principles and practices of order and authority. Like many other French legal professionals and judges who faithfully served the Vichy government, ${ }^{35}$ he did not refuse to perform his duty when he was appointed a judge, even though he considered it a heavy burden. Indeed, being a rigorous researcher and a scholar educated in the tradition of classical legal thought, he conducted his part in the investigation and hearings as diligently as any of his scholarly pursuits, which ultimately contributed to the failure of this political trial.

\section{The Olivier-Martin library as a reflection of its former owner}

Taking into account the personality, beliefs, and career of Olivier-Martin, could it be hoped that his research library, collected during his scholarly career of almost half a century, accurately reflects them all? The results of the analysis of his library presented below show that in fact, if he was not known to be a leading authority on the subject of French legal history, a talented and charismatic educator, a mentor loved and esteemed by his students, and a thorough researcher passionate about the history of old French law, while at the same time a monarchist infatuated by the legal order of the Ancien Régime, all this is evident or could be easily deduced by studying the books that constitute his library.

It has been demonstrated before that the analysis of the contents of a private library can be of 'great value for historians and biographers seeking to study the author's 
position' within a network, literary or scientific. ${ }^{36}$ Olivier-Martin's library shows his connections to past, contemporary, and emerging generations of French legal historians, his position within the contemporary academic community, and his influence and authority as an educator and scholar, as well as the regard in which he was held by his peers and his students. Numerous books in his library are inscribed to Olivier-Martin by their authors, some by his mentors, and many more by his former students and future colleagues, while other volumes contain correspondence with the books' authors or book reviews written by Olivier-Martin. Of the total of 775 books, some 260 contemporary titles are inscribed by their authors, many bearing not just a signature or a formal 'to ... from'-style inscription but words of respect and admiration, while thirty-one books have correspondence with their authors laid in them.

His connection with the previous generation of French legal historians on a personal level is manifested through several books inscribed 'à mon cher ami Olivier-Martin' or 'mon cher collègue et ami Olivier-Martin' by his mentors Émil Chénon and Charles Lefebvre, with whom he took courses during his doctoral studies and whom he succeeded as the leading authority on French pre-revolutionary law. ${ }^{37}$ Other books testify to his professional connections to his academic predecessors. Several published theses, for example, La prise à partie dans l'ancien droit français, list Olivier-Martin as a member of examination committees under the presidency of his mentor, Chénon. ${ }^{38}$ Other examples include an invitation to Olivier-Martin to contribute to the Festschrift for Adhémar Esmein, which he kept in the book authored by the latter, ${ }^{39}$ while the efforts of Olivier-Martin to publish posthumously the second volume of the magisterial work of Chénon, Histoire générale du droit français public et privé des origines à I8I5 (I926), which were acknowledged on the title page of the volume. ${ }^{40}$

Olivier-Martin's influence and authority as a scholar and academic mentor among contemporary legal historians, including his political opponents, is convincingly illustrated by the books in his library that were inscribed to him or that have letters from the authors laid in them. Not surprisingly, many of the authors of the inscriptions and letters were or would have become academics or parliamentarians, but probably contrary to expectations, many of them were on the side of the political spectrum completely opposite to the conservative, Catholic, and monarchist Olivier-Martin. Among them are future members of la résistance, a minister of the Front populaire government, and a unionist. ${ }^{4 \mathrm{I}}$ Examples of the inscriptions include, to cite just a few: '`̀ Monsieur Olivier-Martin, qui est le grand père de ce travail, en témoignage de très vive reconnaissance et de très respectueuse affection' (I937), 'À monsieur le Professeur Olivier-Martin dont le vivant enseignement a su me faire aimer l'histoire de la France d'autrefois. Hommage respectueux et reconnaissant' (I945), and 'À mon maître éminent F. Olivier-Martin respectueux hommage' (I95I). In the letters addressed to Olivier-Martin, their authors seek his opinion about their publications, express their esteem for Olivier-Martin's academic authority, and thank him or ask him for his help, advice, or reviews of their books. These letters are illustrative not only of Olivier-Martin's academic achievements and influence but also of the unfailing interest and assistance that he generously extended to many young scholars and former students. Most of the letters make references to past conversations or written exchanges, while some books contain several letters, a direct evidence of the ongoing correspondence. For example, a recent doctoral student and a teacher at the Lycée des Sens sent to Olivier-Martin his 
published thesis (1935), in which, apparently, Olivier-Martin had expressed an interest and thanked him in the accompanying letter for his 'intervention en ma faveur à la commission juridique de la Caisse nationale des Sciences'. Another example is the correspondence between Olivier-Martin and an author, a distinguished jurist, academic, and left-wing politician, found in two of his books published in I939 and I945. In the correspondence found in the 1939 volume, the author writes that the letter sent to him by Olivier-Martin on the occasion of the publication of his first book with evidently favourable opinion was 'magnifique récompense [...] d'un effort long et parfois aride' and expresses a hope that Olivier-Martin could publish a book review of this work in the Revue historique du droit. A remarkably flattering six-page-long book review was published in 1942, where Olivier-Martin praises not only the scientific merits but also the objectivity of the work not influenced by the author's own political views, both qualities evidently dear to Olivier-Martin himself. In a follow-up letter, sent on 8 October I942, the author was profoundly touched by 'cette belle analyse, empreinte d'une visible sympathie scientifique et presque personnelle' that was especially precious to him because it was written by 'un maitre tel que vous'. In the correspondence found in the second book, published in I945, the same author assured Olivier-Martin of his 'fidèle sympathie' and of how precious for him would be a future review of this other work by Olivier-Martin.

Heather Jackson has demonstrated convincingly that marginalia in books can be a gold mine for researchers. ${ }^{42}$ Olivier-Martin's marginalia, material evidence of the mental work and thought processes of a scholar, capture his teaching, research, and writing processes as they were happening in real time. They tell a story of the genesis of his works and reveal a methodical, rigorous, and tireless researcher and a thoughtful mentor, mirroring the impression left by the inscriptions in the books and the correspondence discussed above. Olivier-Martin's marginalia range from simple marginal markings to notes on the margins, notes on flyleaves, and notes on particular passages written on separate pieces of paper laid into the books. A testimony to Olivier-Martin's methodical and thorough manner of work is the fact that his research notes, received letters, newspaper clippings, and even marginalia are almost always dated, while book reviews and articles cut out of journals give the publication title, volume, and date marked on the margin. Also, it is worth noting that Olivier-Martin's marginalia are not found in any of the early pre-I800 books, where his notes were always made on separate sheets of paper laid into the books, for example the notes in his I 552 copy of Notitia dignitatum. ${ }^{43}$ His only markings made in thirty-one of his seventy-nine pre-I 800 books are his signature and the date of acquisition on the front flyleaf, which shows that he was a reader capable of appreciating and respecting the integrity of these early printed volumes.

There are $\mathbf{I} 77$ books in his library in which Olivier-Martin, an attentive reader always alert to new information or interesting facts pertaining to his area of study, marked some sentences or paragraphs with a characteristic vertical stroke. His extensive research or critical notes appear in IOI books, marginally or laid in on separate sheets of paper that can be several pages long. In these notes, Olivier-Martin often added more information or additional references to the point discussed by the author in a particular passage, as he did on page 297 of the first volume of the Histoire générale $d u$ droit français public et privé des origines à ${ }_{18}{ }_{15}$ (I926), where he added to the 
footnote information on an available translation of a Carolingian capitulary. ${ }^{44}$ In some other books Olivier-Martin translated specific passages and commented on the text, sometimes from Latin, as in Brutus (I886), or from Latin and Greek as in the first volume of Thucydides (I875), where in addition to numerous translations throughout the text he wrote two pages of comments in minuscule handwriting at the beginning of the book. ${ }^{45}$

In other notes, Olivier-Martin corrected wrong references, misspellings, and imprecise quotations or contested conclusions that he thought erroneous. This type of marginalia is often but not exclusively found in published theses where Olivier-Martin was a member of the examination committee or in books that he had been sent to review. For the thesis Les cabiers de paroisses (1939), Olivier-Martin wrote a number of notes on two sheets of paper referring to individual passages or pages, such as 'p. 9 punctuation', 'I|style p. 44 || p. 60', 'class[ment] des doléances, p. 52-53 défectueux', 'p. IO-II, schéma historique peu exact', and some general comments: 'les cahiers sont intéressant; carte [double underlining], annotations et bibliographie, intéressantes [double underlining]'. ${ }^{6}$ The marginalia to another thesis, La chambre des comptes de Dijon à l'époque des ducs Valois (1924), include numerous marginal markings, marginal notes, and notes on a piece of paper laid into the book. ${ }^{47}$ On page I3, Olivier-Martin contests the date of I 350 given for the separation of the Courts of Finances of Paris from Curia regis and marks for himself the opinion of his mentor Chénon, noting, 'parait exagéré à $M$. Chénon; il préfère la date de I320-.' In the same thesis, on page II5, Olivier-Martin writes next to a paragraph discussing authority in the ducal domain, 'N'a rien à voir avec la question du domaine. Règlement intérieur', further elaborating this note on a separate piece of paper.

In the books that Olivier-Martin reviewed for a journal, a similar pattern of notes can be seen. For example, in Histoire de la lettre de change en France aux XVIIe et XVIIIe siècles (I933), a book he was to review favourably, he added an additional reference ('Début du Capitalisme, I927, p. 266-308') to note 4 at page $13 .{ }^{48}$ In another reviewed book, De la légitimation par 'lettres royaux' (1923), Olivier-Martin made numerous typographical corrections, added references, and wrote comments alongside passages in the text that he found unconvincing. ${ }^{49}$ For example he writes 'a-t-il vu les texts effectivement?' next to note 2 on page 45 , where the author cited several archival documents; on page 148 , he marks with 'erreur' a passage that discusses royal power in relation to the succession clauses in the testaments; and on page 188 , he concludes 'ceci contredit [...] les belles explications qui precedent' next to a paragraph on the role of parliament.

In two of Olivier-Martin's own works, Histoire de la coutume de la prévôté et vicomté de Paris (1922-30) and L'organisation corporative de la France d'Ancien Régime (1938), there are tens of marginal notes, articles cut from newspapers and journals, book reviews, and notices of new publications cut from booksellers' catalogues, as well as notes, references, and citations written on the backs of letters or invitations or on pieces of paper torn from notebooks. They are possibly the best illustration of the constant focus of his scholarly interests, the tirelessness of his research efforts, and his almost absolute absorption in the subject. Olivier-Martin continued to add newly discovered facts and references to recently published books and articles to both Histoire de la coutume and L'organisation corporative from the moments of their publication 
almost until his death in early I952, with some notes dated as late as July I950. In February 1944 , he wrote a note to page 223 of Histoire de la coutume on the division of fiefs in the fifteenth and sixteenth centuries referencing pages I60-6I of a thesis recently defended at the École des Chartes by Edouard Leroux. ${ }^{50}$ In L'organisation corporative, there are two notes on page 25: one made on the bottom margin on 2I February 1943 is about an article published in Revue d'histoire de l'église that contained, according to Olivier-Martin, a rather extended bibliography, while the second, made on a piece of paper on I6 July I949, alludes to a newly published book, The Nations in the Mediaeval Universities (I948). ${ }^{5 \mathrm{I}}$ The dates of some of the notes taken in the midst of the Second World War, and especially those articles that Olivier-Martin cut from newspapers of the period, are a perfect illustration of the padded existence of this scholar ever absorbed in his subject, 'l'existence ouatée', as described in the pamphlet commemorating his retirement. ${ }^{52}$ For example, the back of the article 'Le congrès des imprimeurs sur étoffes met fin à la lutte des classes', published on Io October I94I, which OlivierMartin carefully cut out of a newspaper, features reports on the ongoing Battle for Moscow, one of the bloodiest encounters of the period, which obviously did not attract as much of his attention as the article celebrating the triumph of corporatism.

A large number of theses, published as monographs after being defended, found in his library give an additional glimpse into Olivier-Martin's busy academic life. In total, there are II 8 theses published between I900 and I95I. Their presence in his library cannot be attributed only to the call of duty because even if he could have received ex officio, as the head of the examination committee or one of its members, a half of them, sixty-six theses, they could have been easily discarded. These publications are rather a testimony to his active work as a teacher and an attentive and sought-after academic mentor and also to his interest in following contemporary and emerging scholarship in his field. This interest as well as his consistent collection-building efforts are also manifested through a considerable number of book reviews cut from journals, book order forms, and bookseller advertisements (more than forty in total) found in the books. The distribution of the dates of publications, with the majority of the titles published in the twentieth century, once again reinforces an image of Olivier-Martin as an active scholar collecting the contemporary research output on the subjects of interest to him, with the vast majority of the books published during his lifetime (see Table I).

With regard to the preservation and care of his books, Olivier-Martin demonstrated the thoroughness and correctness that were so characteristic of him. Even though he

TABLE 1

OLIVIER-MARTIN'S LIBRARY: PUBLICATION DATES.

\begin{tabular}{lr}
\hline Date of Publication & Number of Titles \\
\hline $1501-1600$ & 5 \\
$1601-1700$ & 29 \\
$1701-1800$ & 46 \\
$1801-1900$ & 80 \\
$1901-1952$ & 615 \\
Total & 775 \\
\hline
\end{tabular}


was not a bibliophile, his library portrays him as a thoughtful and careful reader and collector who strived not only to build but also to preserve his book collection. For example, he had rebound, in modest but serviceable hard covers by the binder Vitoz, most of the contemporary paperbacks acquired while he was still teaching at the University of Rennes. Incidentally, this binder is still in business and is still using a binding style similar to that used for the Olivier-Martin's books. ${ }^{53}$

The analysis of the subject matter of his library demonstrates its perfect accordance with the main academic interests of its former owner, a legal historian, absorbed in the study of the legal order of the Ancien Régime, who taught French legal history for more than twenty-five years (see Table 2). The vast majority of the library is composed of titles on various aspects of legal history, economic history, and history in general in the period before the French Revolution, with books on the legal history of France and French cities, territories, and provinces constituting close to one-fourth of the collection (2I4 titles). The geography of the places of publication, with 9I percent of the titles constituting the collection being published in France, is another indication of the subject focus of his library, as in the first half of the twentieth century books on French legal history were generally published in France.

In addition to the insight into the scholarly interests of Olivier-Martin, his library provides a glimpse into his political beliefs, as well as an indication of their convergence. The absence of even a single copy of the Civil Code in the research library of the staunch monarchist is telling but not truly surprising, while a large number of publications on canon law and church history is testimony to the twenty years' service of this devout Catholic in le Conseil d'administration de la Société d'histoire ecclésiastique de la France. Also, the academic interest in the history of professional corporations and institutions of a co-founder of la Société Jean Bodin pour l'histoire comparative des institutions, as well as his adherence to the corporatist theory, which he continued to

TABLE 2

OLIVIER-MARTIN'S LIBRARY: SUBJECTS OF BOOKS.

\begin{tabular}{lr}
\hline Subject Group & Number of Titles \\
\hline Legal history-France & 171 \\
History-France & 75 \\
History-French cities, territories, and provinces & 71 \\
Customary law & 60 \\
Economic history-France and Europe & 56 \\
Canon law; church governance and administration & 49 \\
Church history; history of religious orders & 47 \\
History of institutions, including state institutions & 44 \\
Legal history-French cities, territories, and provinces & 43 \\
Corporatism; estates; professional guilds and corporations & 39 \\
History-Europe & 29 \\
Legal history-Europe & 29 \\
Roman law & 23 \\
History, general, including history of individual countries outside Europe & 21 \\
French language and literature-history & 18 \\
Total & 775 \\
\hline
\end{tabular}


defend even after the collapse of the corporatist model established by the Vichy regime,${ }^{54}$ is manifested in the substantial number of publications on the subject.

\section{Conclusion}

The study of the Olivier-Martin library highlights once again several important truths about book collections and private libraries. First, not only do individual physical books have value as historical artefacts, but also 'books can say something unique as a collective unit'. ${ }^{55}$ Private libraries and book collections let us listen to the silent voices of readers of the past. They are material evidence of bygone lives that supplement information about the work, beliefs, and actions of their former owners available in other sources, or they can act as such in its absence. Second, while studying and especially when reconstructing private libraries and book collections, it is essential to use multiple sources of evidence of their provenance and ownership, supplementing physical evidence found in the books with archival records. Also, private libraries and book collections are 'remnants of the material culture of bygone era [which] help channel' the past ${ }^{56}$ and give to the researcher an intangible but no less real feeling of the spiritual presence of the person who gathered the collection and worked with the books that form it. This feeling is created by what Gerald Beasley calls the 'empathetic access' to material collections, by the fact of opening, holding, and reading the same books that the person who collected the library opened, held, and read. ${ }^{57}$ Finally, private libraries that belonged to the scholars of the past can act as time capsules of history, general, intellectual, or disciplinary, and help modern researchers immerse themselves in the days gone by with all their conflicts, errors, and contradictions, allowing us to live the past in the present.

\section{Acknowledgements}

I am profoundly grateful to Megan Chellew, cataloguing coordinator of McGill Library, who read and commented on the first draft of this article. My deepest gratitude is to Mtre Daniel Boyer, the head of the Nahum Gelber Law Library, who inspired me to work on this project.

\section{Notes}

I F. Mauriac, Oeuvres autobiographiques, Bibliothèque de la Pléiade, 367 (Paris: Gallimard, I990), p. 472 .

2 See for example B. Aitchison and P. H. Reid, "“The Owner of One of the Largest and Most Valuable Private Libraries in Scotland": David Hay Fleming as Book Collector', Library \& Information History, 3I.2 (2015), 95-II6; P. Arbaizar, 'La bibliothèque de l'écrivain', in Histoire des bibliothèques françaises, ed. by Martine Poulain (Paris: Éditions du Cercle du librairie, I992), pp. II-30; R. W. Beales, 'Ebenezer Parkman's World of Print: A Country Parson and the Print Culture of Eighteenth-Century Anglo-America', Library \& Information History,
3I.4 (2015), 229-257; W. Cibbarelli, 'Libraries of the Mind: A Study of the Reading Histories of Mercy Warren, Abigail Adams and Judith Sargent Murray (I728-I820)' (unpublished doctoral thesis, State University of New York at Stony Brook, 2000); K. Davies and G. Fichtner, Freud's Library: A Comprehensive Catalogue (London: Freud Museum, 2006); S. Ducas, 'La Bibliothèquecénotaphe de Richard Millet: posture de l'écrivain en nouveau moraliste?', Littératures, 63 (2010), I936; N. Ducimetière, 'Un lecteur à l'oeuvre: Malherbe et sa pratique des livres', Dix-septième siècle, 260.65 (20I3), 40I-428; A. Fernandez, 'Albert Mayrand's Private Law Library: An Investigation of the 
Person, the Law of Persons, and "'Legal Personality" in a Collection of Law Books', University of Toronto Law Journal, 53.I (2003), 37-64; R. Jarvis, 'William Beckford: Travel Writer, Travel Reader', The Review of English Studies, 65.268 (2014), 99II7; S. E. Johnson, 'Moreau de Saint-Méry: Itinerant Bibliophile', Library \& Information History, 3I.3 (20I5), I7I-I97; E. Potten, 'Beyond Bibliophilia: Contextualizing Private Libraries in the Nineteenth Century', Library \& Information History, 3I.2 (20I5), 73-94; D. Rhodes, 'Barnard Hampton and His Books', The Library, I5.3 (2014), 343-346; D. Roberts, “"Abundantly Replenisht With Books of His Own Purchasing and Choyce”: Lord Herbert of Cherbury's Library at Montgomery Castle', Library \& Information History, 3 I.2 (20I5), II7-I36; J. Tomm, 'The Imprint of the Scholar: An Analysis of the Printed Books of McGill University's Raymond Klibansky Collection' (unpublished doctoral thesis, McGill University, 20I3); M. Wranovix, 'Ulrich Pfeffel's Library: Parish Priests, Preachers, and Books in the Fifteenth Century', Speculum, 87.4 (20I2), II25-II55.

3 R. Chartier, The Author's Hand and the Printer's Mind (Cambridge, UK: Polity Press, 20I4), p. vi.

4 Ibid.

5 For the history of acquisition of the Olivier-Martin library, see M. Scott, 'The Wainwright Collection', McGill Law Journal, 8 (I96I), 57-60, and M. L. Renshawe and J. E. C. Brierley, 'Sources of Civil Law: The Wainwright Collection', Fontanus, I (I988), 77-83.

6 Renshawe and Brierley; Scott.

7 D. de Boronkay, Olivier-Martin's Collection of Books on French Legal History, History, Church History, Canon Law, Political Science, Public Finance, Etc.: Analytical Bibliography (Montreal: McGill University Law Library, I960).

${ }^{8} \mathrm{~J}$. Wales, 'The Birth of Wikipedia', TED talk, August $2006<$ https://www.ted.com/talks/jimmy_ wales_on_the_birth_of_wikipedia/transcript?langu age $=$ en $>$ [accessed II February 20I5]; see for example A. van Deursen and J. van Dijk, 'Using the Internet: Skill Related Problems in Users' Online Behavior', Interacting With Computers, 2I.5-6 (2009), 393-402.

9 Boronkay.

Io Pierre Abel, Observations sommaires sur la coûtume de Bretagne: Pour faire connoitre le sens qu'elle avoit dans son origine, et celui que l'usage lui a donné, avec la reduction de la même coûtume, selon l'ordre des matières, et la pratique ordinaire du palais (Laval: Amboise, I689).

II C. de Ferrière, Nouvelle introduction à la pratique: Contenant l'explication des termes de pratique, de droit of de coutumes, avec les jurisdictions de France (Paris: Chez Saugrain Fils, I758).
I2 S. Bedford, The Best We Can Do: An Account of the Trial of John Bodkin Adams (London: Collins, I958).

I3 French sources used in this section unless cited otherwise or directly quoted are (French-English translation by the author): $\grave{A}$ monsieur François Olivier-Martin: En l'honneur de sa 46e année d'enseignement (Toulouse: Impr. F. Boisseau, I95I); P. Bonin, 'L'historiographie de l'histoire de droit', in L'histoire du droit en France: Nouvelles tendances, nouveaux territoires, ed. by J. Krynen and B. D'Alteroche (Paris: Classiques Garnier, 20I4), pp. 53358; H. Danesi, 'Olivier-Martin, François JeanMarie', Comité des travaux historiques et scientifiques, I2 December 20 I2 <http://cths.fr/an/prosopo. php?id=III472> [accessed II February 20I5]; P. Deschamps, 'Éloge funèbre de M. François OlivierMartin, membre ordinaire', Comptes rendus des séances de l'Académie des inscriptions et belleslettres, 96.I (1952), I58-I63; 'François Olivier-Martin', World Biographical Information System Online (Farmington Hills, MI: Thomson Gale, 2004) $<$ http://db.saur.de/WBIS/welcome.jsf $>$ [accessed II February 2015]; F.-L. Ganshof, 'François OlivierMartin (I879-1952)', Revue belge de philologie et d'histoire, 30.3-4 (I952), I282-I287; G. Lepointe, 'François Olivier-Martin (I879-I952)', Revue historique de droit francçais et étranger, 30.I (I953), I29; 'Necrologie: In memoriam François OlivierMartin', Legal History Review, 20 (I952), 38I-383; 'Olivier-Martin, François Jean-Marie', SIPROJURIS: Système d'information des professeurs de droit (I804-I950) <http://siprojuris.symogih.org/siproju ris/enseignant $/ 568 \mathrm{I} 7>$ [accessed 20 January 20I6]; J. Poumarède, 'Olivier-Martin, François-JeanMarie', in Dictionnaire historique des juristes français: XIIe-XXe siècle, ed. by P. Arabeyre, J.-L. Halpérin, and J. Krynen (Paris: Presses Universitaires de France, 2007); J. Poumarède, 'Penser l'absolutisme: Approche historiographie des ouvrages pédagogiques en histoire des institutions françaises', in Itinéraire(s) d'un historien $d u$ droit: Jacques Poumarède, regards croisés sur la naissance de nos institutions (Toulouse: CNRS-Université de Toulouse-Le Mirail, 20II), pp. 63I-640.

${ }^{\mathrm{I}}$ For example, G. Tessier, 'L'audience du sceau: Hommage à M. François Olivier-Martin', Bibliothèque de l'école des chartes, I09.I (I95I), 5I-95.

I5 À monsieur François Olivier-Martin.

I6 Ibid.; Lepointe.

I7 See for example P. Cot, Le procès de la République (New York: Éditions de la Maison Française, 1944); S. Hoffmann, 'Les études sur Vichy en France: Avant et après Paxton', in La France sous Vichy: Autour de Robert O. Paxton, ed. by S. Fishman, J.P. Azéma, and R. O. Paxton (Brussels: Complexe, 2004), pp. 63-74; R. H. Soltau, French Political 
Thought in the Igth Century (New York: Russell \& Russell, I959).

I8 F. Olivier-Martin, Histoire de la coutume de la prévôté et vicomté de Paris (Paris: Leroux, 1922-30).

I9 F. Olivier-Martin, L'organisation corporative de la France d'Ancien Régime (Paris: Sirey, 1938); Histoire $d u$ droit français des origines à la Révolution (Paris: Domat Montchrestien, I948).

$20 \mathrm{M}$. Bloch and L. Febvre, Correspondance (Paris: Fayard, I994); R. Descimon, 'Declareuil (I9I3) Contre Hauser (I9I2)', Annales: Histoire, sciences sociales, 57.6 (2002), I6I5-I636; F. Lot, 'Une histoire du droit français [Fr. Olivier-Martin. Histoire $d u$ droit français des origines à la révolution]', Journal des savants, I.I (I949), I4-29; F. Olivier-Martin, 'La prévention et les justices seigneuriales', Comptes rendus des séances de l'Académie des inscriptions et belles-lettres, 83.6 (I939), 6I7-6I8.

2I Descimon; François Olivier-Martin, L'Absolutisme Français (Paris: Éd. Loysel, I988).

22 Bonin, 'L'historiographie de l'histoire de droit'; Descimon; J.-L. Halpérin, 'Est-il temps de déconstruire les mythes de l'histoire du droit français?', Clio Themis: Revue électronique d'histoire $d u$ droit, 5 (2OI2) <http://www.cliothemis. com/Est-il-temps-de-deconstruire-les $>$ [accessed II February 20I5]; S. L. Kaplan, 'Un laboratoire de la doctrine corporatiste sous le régime de Vichy: l'institut d'études corporatives et sociales', Le mouvement social, 2.195 (200I), 35-77.

23 J.-L. Bourgeon, 'Mousnier Roland (I907-I993)', in Encyclopadia universalis <http://www.universalisedu.com/encyclopedie/roland-mousnier $>$ [accessed II February 20I5].

24 Bonin, 'L'historiographie de l'histoire de droit'; P. Bonin, 'Entre républicanisme militant et nostalgie monarchiste: Les manuels d'histoire du droit d'Esmein à Olivier-Martin', paper presented at 'Journée d'étude programme SAB GENEPEJ, École de droit de Sciences Po: “'Histoire du droit, politique et idéologie. Enquête sur les fondements idéologiques d'une discipline juridique"', École de droit de Sciences Po: Paris, 20II; A.-S. Chambost, Histoire des manuels de droit: Une histoire de la littérature juridique comme forme $d u$ discours universitaire (Issy-les-Moulineaux: LGDJ, 20I4); Halpérin; J. Hilaire, 'Les orientations de l'historiographie de droit privé entre I850 et 1950', in Histoire de l'histoire du droit, ed. by J. Poumarède (Toulouse: Presses de l'Université de Toulouse I, 2006), pp. 237-255.

25 Bonin, 'L'historiographie de l'histoire de droit'.

26 Poumarède, 'Olivier-Martin, François-Jean-Marie'.

27 H. Amouroux, La grande histoire des Français sous l'occupation (Paris: R. Laffont, 1997).

28 See for example J.-P. Azéma and F. Bédarida, La France des années noires (Paris: Seuil, I993); J.-P.
Azéma and F. Bédarida, Le régime de Vichy et les Français (Paris: Fayard, 1992); R. O. Paxton, Vichy France: Old Guard and New Order, I940-I944 (New York: Knopf, 1972).

29 Cot; P. Béteille and C. Rimbaud, Le procès de Riom (Paris: Plon, I973); J.-D. Bredin, L'infamie: le procès de Riom, Février-Avril 1942 (Paris: Grasset, 20I2); M. Ribet, Le procès de Riom (Paris: Flammarion, I945); H. Michel, Le procès de Riom (Paris: Albin Michel, 1979).

30 A. Bancaud, Une exception ordinaire: La magistrature en France 1930-1950 (Paris: Gallimard, 2002); M. Curtis, Verdict on Vichy: Power and Prejudice in the Vichy France Regime (New York: Arcade Publishing, 2003); Y.-F. Jaffré, Les tribunaux d'exception: 1940-1962 (Paris: Nouvelles Éditions Latines, I962); J. Laughland, A History of Political Trials: From Charles I to Saddam Hussein (Oxford: Peter Lang, 2008); A. Shennan, The Fall of France, I940 (Harlow, England, and New York: Longman, 2000); La justice des années sombres, I940-I944, ed. by P. Truche (Paris: Documentation Française, 200I).

3 I See nn. 27 and 29 above, as well as M.-O. Baruch, Servir l'etat français: L'administration en France de I940 à 1944 (Paris: Fayard, 1997); M.-O. Baruch, Une poignée de misérables: l'épuration de la société française après la seconde guerre mondiale (Paris: Fayard, 2003); M.-O. Baruch and V. Duclert, Serviteurs de l'état: Une histoire politique de l'administration française, I875-1945 (Paris: La Découverte, 2000); M.-O. Baruch, V. Duclert, and A. Bancaud, Justice, politique et république: De l'affaire Dreyfus à la guerre d'Algérie (Brussels and Paris: Complexe, 2002); M. Olender, Juger sous Vichy (Paris: Seuil, I994); and especially C. Millon, Occupation allemande et justice française, Nouvelle bibliothèque de thèses, I07 (Paris: Dalloz, 20II), a detailed study, drawing on both French and German archival and secondary sources, on the functioning of French legal system under the Nazi occupation. It contains an extensive bibliography on the legal aspects of the Vichy regime including special jurisdiction courts.

32 The archives of the Riom Trial (extending for 17.5 metres) can be found in the nonrestricted access in the Archives nationales de France; for the detailed description see the finding aid <http://www.archi vesnationales.culture.gouv.fr/chan/chan/fonds/edi/ $\mathrm{sm} / \mathrm{W}_{2}$.pdf $>$ [accessed II February 20I5].

33 Michel, p. 73.

34 Ibid.; see also A. Bancaud, 'Une exception ordinaire: Les magistrats et les juridictions d'exception de Vichy', in La justice des années sombres, ed. by Truche, pp. 29-74; Bancaud, Une exception ordinaire.

35 La justice des années sombres, ed. by Truche; Curtis. 
36 W. Silverman, The New Bibliopolis: French Book Collectors and the Culture of Print, I880-I9I4 (Toronto: University of Toronto Press, 2008), p. I43; see also Tomm, 'The Imprint of the Scholar'.

37 E. Chénon, Histoire générale du droit français public et privé des origines à I8I5 (Paris: Sirey, I926), I; C. Lefebvre, Cours de doctorat sur l'histoire $d u$ droit matrimonial français (Paris: Sirey, 1906-23), vol. for I9I2.

38 P. Pallu de Lessert, La prise à partie dans l'ancien droit français (Paris: Presses universitaires de France, I922).

39 A. Esmein and R. Génestal, Cours élémentaire d'histoire du droit français: à l'usage des étudiants de première année (Paris: Sirey, I92I).

40 Chénon.

4I The names of the authors and correspondents, as well as titles of the books inscribed to Olivier-Martin or containing the correspondence, are withheld for privacy concerns.

$4^{2}$ H. J. Jackson, Marginalia: Readers Writing in Books (New Haven and London: Yale University Press, 200I).

43 G. Gelenius and A. Alciati, Notitia vtraque cum orientis tvm occidentis vltra Arcadii honoriique Casarvm tempora (Basileae: Apvd H. Frobenivm et Episcopivm, I552).

44 Chénon.

45 M. T. Cicero, Brutus: Für den Schulgebrauch (Leipzig: Druck, I889); Thucydidis de bello peloponnesiaco, libri octo (Leipzig: in aedibus B. G. Teubneri, I875).

$4^{6}$ Y. de Bohineust de Boulardiere, Les cahiers de paroisses de l'élection du Blanc-En-Berry pour les états généraux de 1789 (Paris: Les Presses Modernes, I939).

47 E. Andt, La chambre des comptes de Dijon à l'époque des ducs Valois (Paris: Sirey, 1924).

$4^{8}$ H. Lévy-Bruhl, Histoire de la lettre de change en France aux XVIIe et XVIIIe siècles (Paris: Sirey, I933).

49 L. Delbez, De la légitimation par 'lettres royaux': Étude d'ancien droit français (Montpellier: Impr. de l'économiste Méridional, I923).

50 E. Leroux, 'Le bailliage du palais de I359 à I7I2' (unpublished doctoral thesis, École des Chartes, I944).

5 I L. Rigaud, 'La nation germanique de l'ancienne université d'Orléans', Revue d'histoire de l'église de France, 27.III (I94I), 46-7I; P. Kibre, The Nations in the Mediaeval Universities (Cambridge, MA: Mediaeval Academy of America, 1948).

52 À monsieur François Olivier-Martin.

53 Maison Vitoz, 'La reliure artisanale depuis I860' $<$ http://www.vitoz-reliure-dorure.fr $>$ [accessed II February 2015].

54 Poumarède, 'Penser l'absolutisme'.

55 J. Tomm, 'Talking Books and the Dorothea Effect: Explorations in the Raymond Klibansky Collection', in Meetings With Books: Special Collections in the 2Ist Century, ed. by Richard Edmund Virr and Jillian Tomm (Montreal: McGill University Library and Archives, 20I4), p. I80.

56 Silverman, p. I47.

57 G. Beasley, 'Curatorial Crossover: Building Library, Archives, and Museum Collections', RBM: A Journal of Rare Books, Manuscripts and Cultural Heritage, 8.I (2007), 28.

\section{Notes on contributor}

Svetlana Kochkina is a librarian at McGill University Law Library and a PhD candidate at McGill School of Information Studies. Her main research interests include the evolution of the form and paratextual elements of the book; the history of publishing and book collecting; and the history of institutional and private libraries. She is a member of the Bibliographical Society of Canada and the Canadian Association for the Study of Book Culture.

Correspondence to: Svetlana Kochkina. Email: svetlana.kochkina@mcgill.ca 